\title{
Measurement of the Effectiveness of Off-the-Job Training Methods in Commercial Banks of Bangladesh
}

\author{
Shahin Akther ${ }^{1}$, Javed Tariq ${ }^{2} \&$ Nazrul Islam ${ }^{3}$ \\ ${ }^{1}$ Faculty Member, Training Institute, Mercantile Bank Limited, Dhaka, Bangladesh \\ ${ }^{2}$ Principal, Training Institute, Mercantile Bank Limited, Dhaka, Bangladesh \\ ${ }^{3}$ Pro-Vice-Chancellor, Canadian University of Bangladesh, Dhaka, Bangladesh \\ Correspondence: Shahin Akther, Faculty Member, Mercantile Bank Training Institute, 41/6, Purana Paltan, \\ Dhaka-1000, Bangladesh. E-mail: shahustc@gmail.com
}

Received: June 29, 2019

Accepted: July 24, 2019

Online Published: August 22, 2019

doi:10.5539/ijbm.v14n9p160

URL: https://doi.org/10.5539/ijbm.v14n9p160

\begin{abstract}
Banks and financial institutions of Bangladesh invest a large amount of money for training purposes in building and enhancing capacity of their human resources. But whether this investment is effective or not is a question often asked by the policymakers of these institutions. These institutions usually train their employees by using off-the-job training methods like seminars, workshops, lectures, etc. along with on-the-job training methods to improve the performance of the employees. A lion's share of training budget is usually used for off-the-job training purposes that add value for the development of knowledge, skills and abilities (KSA) of the employees'. But the effectiveness of these training methods is often questioned due to traditional lecture-based training sessions. To make the employees more attractive to training programs, interactive and value adding training methods can increase the effectiveness of the training. Hence, this paper aims at identifying the factors that can improve the effectiveness of the off-the-job training methods in commercial banks of Bangladesh. This study used both qualitative and quantitative research methods. A survey was conducted among the bank officers who received off-the-job training with structured questionnaire. A total of 300 bank officers at different levels of the banks were interviewed. Eight leading private and public commercial banks were included in the survey. Factor Analysis was used to identify the factors related to the effectiveness of off-the-job training methods while Multiple Regression was used to identify the relationships between the overall effectiveness of the training and the effectiveness factors related to off-the-job training. Results show that the effectiveness of the off-the-job training methods depends on four significant factors such as, acquiring knowledge and skills, logistics support, invitation of comments by the trainers and participation of the trainees, and participation of the trainees in Training Needs Assessment (TNA). This study suggests that off-the-job training methods can be made more effective by ensuring effective delivery of knowledge, providing proper logistics supports, engaging trainees in training sessions, and ensuring participation of the trainees in training need assessment processes of the banks.
\end{abstract}

Keywords: Off-the-Job training, training effectiveness, logistics support, training needs assessment, On-the-Job Training, knowledge-skills-abilities (KSA)

\section{Introduction}

Banking activities are very important in the context of economic development of any developing country like Bangladesh. Commercial banks have been playing important role by providing investible funds to both the public sector and specially the private sector. Commercial banks have been facilitating payment, finance and risk management services to this sector. As of June, 2018, the total number of bank accounts in Bangladesh stood at 92.10 million, while the total amount of deposits stood at Tk. 10,38,694.36 crores. The total sum of loans increased from Tk. 211,065 crores in 2008 to Tk. $847,012.22$ crores in 2018 which is more than $400 \%$ raise in this period of time. The total number of banks also rose from 47 in 2008 to 58 in 2018 (Note 1). Hence, training effectiveness of training programs is an instrumental for the growth and development of this sector.

Effective training affects change in job performance gradually and also transform employee behavior patterns through the acquisition of new skills, knowledge, and abilities. Therefore, training is used as major means by these organizations to maintain competence and adaptability of the human resources to changing demands of the internal 
and external environment (Banna, 1995). Undeniably, a well trained and developed employee is considered as valuable asset to the banks and thereby increases the chances of their efficiency in discharging their duties (Hameed, Rajinikanth, \& Mohanraj, 2014).

In banks, the methods commonly practiced in training are: On-the-Job Training Methods, Job Instruction Technique (JIT), Demonstration and Simulation, Apprenticeship (Foundation training), Class Room or Off-The-Job Training, etc. Bank provides long duration i.e., week-long or a month-long training to the apprentice as they initially join the bank as fresher. Bank branch managers act as mentors and provide on-the-job training to the new employees. Banks use different training techniques and methods which are mostly related to enhancement of knowledge, skills and abilities of the workers. The trainings are primarily related to banking laws, regulations and guidelines, customer services, marketing techniques, etc. Most of these training programs are off-the-job training in nature. For the achievement of the banks goals, the effectiveness of these off-the-job training methods plays a very important role. Hence, this study aims at measuring the effectiveness of the off-the-job training methods in the commercial banks of Bangladesh.

\section{Objective of the Study}

The main objective of this study is to identify the factors related to the effectiveness of the Off-the-Job Training Methods used by the commercial banks of Bangladesh. The specific objectives are as follows.

- To identify the factors related to the effectiveness of off-the-job training methods in commercial banks of Bangladesh;

- To identify the significant factors concerning the effectiveness of off -the-job training methods;

- To examine the relationships between the effectiveness factors and the overall training effectiveness of the commercial banks in Bangladesh.

\section{Literature Review}

A lack of basic knowledge of banking risks and value drivers by the boards and senior managers of the failing banks were implicated in the banking crisis. These knowledge problems concerned banks' understanding of their organization, intermediation and risk management in an active market setting characterized by rapid economic and organizational change. Khanna and Arora, (2009), identified lack of training' as the important reasons for bank frauds. Thus, the failing banks ignored or were unaware of this knowledge and hence experienced acute difficulties with learning the new knowledge needed to address the new problems thrown up by the financial crisis. By ensuring greater bank learning, knowledge creation, and knowledge use, governments and regulators could help reduce individual bank risk and the likelihood of future crisis (Holland, 2010).

Training and development is beneficial much to employee but the organizations is endowed with its eventual advantage in long run, because the end user of each benefits is the organization itself (Raja, Furqan, \& Muhammad, 2011). According to Herman and Kurt (2009), the benefit of employee training improves organizational performance such as productivity \& profitability, effectiveness, operating revenue per employee (RPE), consequently other results that are also directly and indirectly related to the organizational performance. In this regards, he further mentioned the direct factors of organizational performance as cost effectiveness, improved quality and quantity and employee turnover, organization's reputation, social capital as indirect factors. Even training is a very costly investment in any organization. However, to optimize its effectiveness and efficiency is critical (Martin, Barbara, \& Kolomitro, 2013). Over the year, researcher study on training and development as a part human capital development. Training and development has been acknowledged to be a very important component of organizational performance. According to Raja and Farqun (2011) there is a positive relationship between training design and organizational performance. Similarly, training and development affects employees' performance and organizational effectiveness. Training methods could be classified as cognitive and behavioral approaches.

Smith (2002) had shown 'off-the-job training' as a supplement for workplace learning even though initially he did not put much value to off-the-job training. In his research, he found that the young people gained more of an appreciation, during the course of the year as like off-the-job training had to offer. Some researchers successfully developed linkage between training program (off the job) and employee learning or subsequent performance (Morganand Casper, 2000), relationships between training and learning (Amin, Saeed, Lodhi, Iqbal, \& Tehreem, 2013). In the training program, trainee reactions are multidimensional and evaluating trainee reactions may develop true relationship to other measures of training effectiveness (Morganand Casper, 2000). 
Banks around the world are signifying its' effort on 'lecture method training' visa vie 'off-the-job training method to expedite employee efficiency. In Malaysian Banking Industry, a high proportion of planned on-the-job training and lecture methods (off-the-job training) were reportedly being utilized in training of their banking sales personnel (Jantan \& Honeycutt, 2013). The study also exposed that market-oriented topics generally offered to those salespeople who attended more than 7 days training duration. Some Russian banks was unable to pay for expensive outside training programs, may have to use multimedia and Internet-based training as the only alternative to not having any training at all (Ardichvili \& Gasparishvili, 2001). According to Atiyyah (1993), training programs were usually evaluated via questionnaires distributed to the trainees to give their opinions on the quality of instruction, programmes materials, and suitability of the training techniques. Altarawneh (2009) emphasized on evaluation of external T\&D programmes (off-the-job training) regularly in Jordanian Banking Organization. Karadimas \& Rigopoulos (2006) suggested in their study to improve bank's e-learning environment, synchronous learning tools facilitate to develop the reading material and audio-visual technique along with discussion boards, groupware and use of multimedia creates a good plat form to learn specially IT professionals in Banks.

Training methods could be classified as cognitive and behavioral approaches (Alipour, Salehi \& Shahnavaz, 2009). Cognitive methods also refer as off the Job training method, provides verbal or written information, rules for how to do something and exhibits relationships among concepts. Cognitive training techniques (off-the Job training) have significant effect on employees' optimal performance self-efficacy and creativity (Falola, Osibanjo, \& Ojo, 2014).On the other hand, researchers like Abang, May, and Maw (2009), pointed out that Lynch and Black in their studies revealed that only off-the-job training improves organizational performance whereas on-the-job training does not.

There are two other specific training methods - conceptual models and motivational planning \& management (Bostrom, 1988). Motivational planning \& management is the identification of a learning motivation process through the trainee can be motivated to learn and having a high motivation after training to continue learning. According to Herman and Kurt (2009), several procedures are effective at increasing the benefits of training of the organization. In his study, he suggested some way outs. First, organizations should conduct a needs assessment using experienced subject matter experts to make sure trainees are ready and motivated for training. Second, In terms of training design, organizations should apply theory-based learning principles to encouraging trainees to study the training content, ensure trainees prompt effort in acquisition of new skills, and providing trainees with an opportunity to make errors together with explicit instructions to encourage them to learn from these errors enhances the benefits of training. Finally, state-art-technology should adopt for efficient training delivery.Many teachers and trainers shift the subject from teaching or training on the intended curriculum to teaching the aid technology itself (Ewain, 2005). Therefore, promotion and awareness about training with technology is essential during training delivery.

Many researchers point to the importance of considering off-the-job training effectiveness factors such as self-efficacy, training budget, supervisory support and opportunity to perform as moderators of the relationship between training and transfer of training back to the work environment (Lisa \& Holly, 2007). A training program is inadequate until training methods and results are not evaluated and training effectiveness depends on a systematic approach of measurement and evaluation. Recognition of the training methods and measurement techniques are crucial for the organization's training success (Alipour, Salehi, \& Shahnavaz, 2009). In this connection, many researchers believe and conducted their research incorporating the model for measuring training effectiveness as developed by Donald Kirkpatrick's in late 1950.This model perceived benefits of training from the perspective of various stakeholders in the process, including those who participate in training, and those who fund it i.e. organizations (Jeremic, Jovanovic, \& Gasevic, 2009).

The application of Social Cognitive Theory (SCT) in various field of psychology, education and communication lights on individual's knowledge acquisition which is directly related to the observation within the context of social interactions, experiences, and outside media influences. It acknowledges the human thought, affect, and behavior that are influenced by observation as well as by direct experience (Bandura, Albert \& Walters, 1977). Hence, the underlying concept of Social Cognitive Theory (SCT) is applicable for off-the-job training that is concerned with role playing, lecture and vestibule training. These may influence the perceptions of the trainee to enact their behaviors or give confidence to them and the training becomes effective.

Based on literature review, a conceptual framework of this study has been developed focusing on the personal, behavioral and environmental aspects of the trainees for measuring the effectiveness of off-the-job training in commercial banks of Bangladesh (Figure 1). 


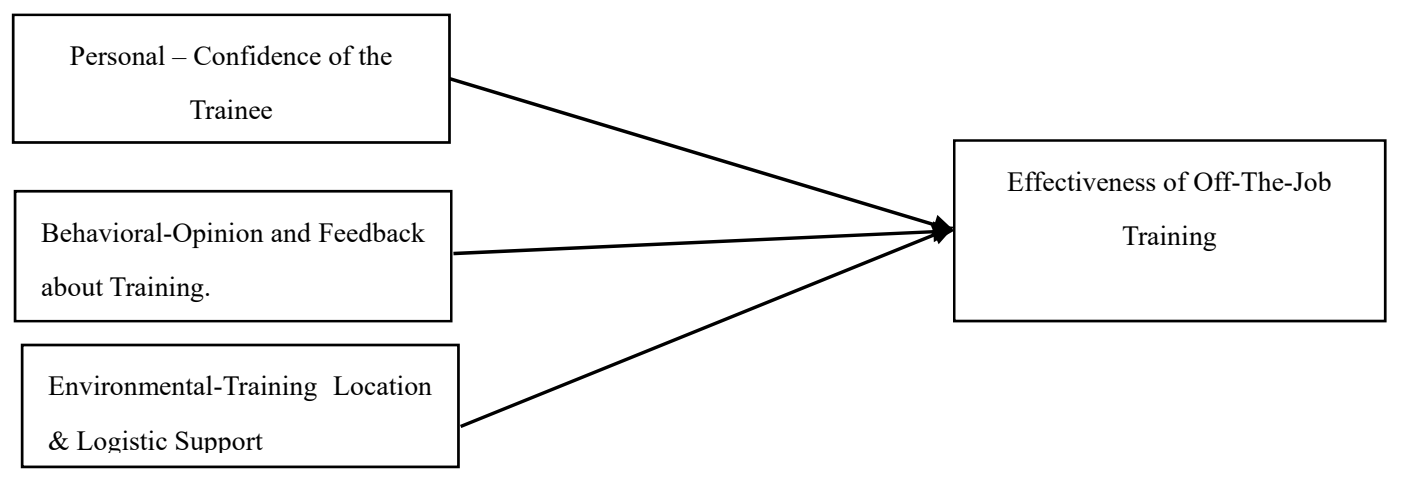

Figure 1. A conceptual framework for the effectiveness of off-the-job training methods in commercial banks of Bangladesh

\section{Research Methodology}

This research is based on secondary and primary data sources. With the secondary sources, data were obtained from various journals, books, research monographs and other publications on training and development. A purposive sampling method is used in view with the study purpose exactly those undertaken the off-the-job training recently. The populations of the study are Private and Public commercial banks of Bangladesh.

\subsection{Respondents' Profiles}

\subsubsection{Age \& Gender Distribution of the Respondents}

Age and gender are important determinants for the effectiveness of training (Van Den Besselaar \& Sandström, 2016). The respondents who were surveyed and interviewed are at the age group from entry level to senior manager. Age group facilitates to understand the number of freshmen employees who have less or no experience and mid level managers who have experience. Study shows that $11.0 \%$ of the respondents are at the category of freshman who need training more and $58 \%$ of the represents are at the age between $26-33$ years who already availed training several times. Likewise, $27.3 \%$ \& 3\% from the age group of 34-41 years and $42-49$ years indicate that these respondents are skilled and knowledgeable with a stable banking career. In this study, 2 respondents were interviewed who are policy makers of the bank.

Among the respondents, only $18.7 \%$ of total numbers of bankers are female. Hence, sample comprised of 244 male officers and only 56 female officers. Total 300 employees were selected from eight private and public commercial banks of Bangladesh who have recently received training from their banks out of job location (Table $1)$.

Table 1. Age \& Gender distribution of the respondents

\begin{tabular}{|c|c|c|c|c|c|}
\hline Variables & Age Limit/Gender & Frequency & Percent & Valid Percent & Cumulative Percent \\
\hline \multirow{7}{*}{$\begin{array}{l}\text { Age of } \\
\text { Respondents }\end{array}$} & $18-25$ & 33 & 11.0 & 11.0 & 11.0 \\
\hline & $26-33$ & 174 & 58.0 & 58.0 & 69.0 \\
\hline & $34-41$ & 82 & 27.3 & 27.3 & 96.3 \\
\hline & $42-49$ & 9 & 3.0 & 3.0 & 99.3 \\
\hline & $50<$ & 2 & .7 & .7 & 100.0 \\
\hline & Total & 300 & 100.0 & 100.0 & \\
\hline & Male & 244 & 81.3 & 81.3 & 81.3 \\
\hline \multirow{2}{*}{ Gender Distribution } & Female & 56 & 18.7 & 18.7 & 100.0 \\
\hline & Total & 300 & 100.0 & 100.0 & \\
\hline
\end{tabular}

Source: Survey Data, 2019. 


\subsubsection{Educational Qualifications and Job Category in Banks}

The banking recruitment process in Bangladesh demands a Master degree preferably from government accredited universities and colleges for both private and public sector banks. Persons with higher degree from internationally recognized institutions are also encouraged to apply for banking jobs in Bangladesh. During professional career in banking, bankers are expected to go through specialized courses such as, banking diploma, anti money laundering course, foreign exchange and credit specialization course, customer service course, etc. Generally, students from business background sought like banking profession. Among 300 respondents, $89 \%$ have their masters' degree and $10 \%$ have bachelor's degrees. Only $1 \%$ of the respondents have completed post graduation degree in banking diploma (Table 2). It is worth to mention here that the banks in Bangladesh possess higher education degree in terms of recruiting its employees. Recently, banks encouraged their employees to do post graduation degree in banking diploma.

According to management hierarchies, $76.7 \%$ respondent employees are at the entry level, $17 \%$ at the mid level, $4 \%$ is at the upper level, $2 \%$ are head of branch, and the rest of the employees are senior management (Decision Maker). Off- The- Job training facilitates mostly entry level to upper mid level employees including bank managers (Table 2).

Table 2. Educational qualifications and job category of the respondents

\begin{tabular}{llllll}
\hline & Name of Degree/Position & Frequency & Percent & Valid Percent & Cumulative Percent \\
\cline { 2 - 6 } & Master's Degree & 267 & 89.0 & 89.0 & 89.0 \\
Educational & Postgraduate Diploma & 4 & 1.3 & 1.3 & 90.3 \\
Qualifications & of Bachelor Degree & 29 & 9.7 & 9.7 & 100.0 \\
Respondents & Total & 300 & 100.0 & 100.0 & 76.7 \\
Job position & of Entry Level & 230 & 76.7 & 76.7 & 93.7 \\
Respondents & Mid Level & 51 & 17.0 & 17.0 & 97.7 \\
& Upper Mid & 12 & 4.0 & 4.0 & 99.7 \\
& Head Of Branch & 6 & 2.0 & 2.0 & 100.0 \\
& Senior Mgt. & 1 & .3 & .3 & \\
\hline
\end{tabular}

Source: Survey Data, 2019.

\subsubsection{Working Experience}

The highest numbers of respondent employees are comparatively young and have less than five years of working experience $(60 \%)$. Only $22 \%$ respondents have $5-10$ years of experience. Whereas, $15 \%$ of total respondents have $10-15$ years working experience and $3 \%$ have $15-20$ years experience (Table 3 ).

Table 3. Working experience of the respondent

\begin{tabular}{lllll}
\hline Range of Years & Frequency & Percent & Valid Percent & Cumulative Percent \\
\hline 1-5 Years & 179 & 59.7 & 59.7 & 59.7 \\
$5-10$ Years & 67 & 22.3 & 22.3 & 82.0 \\
$10-15$ Years & 44 & 14.7 & 14.7 & 96.7 \\
$15-20$ Years & 8 & 2.7 & 2.7 & 99.3 \\
20 years and above & 2 & .7 & .7 & 100.0 \\
Total & 300 & 100.0 & 100.0 & \\
\hline
\end{tabular}

\subsubsection{Sample of Respondents by Bank}

Out of 59 banks, the survey has covered 08 banks which are mostly private banks in Bangladesh. The sample banks are: Dhaka Bank Limited, South Bangla Agriculture Bank Ltd (SBAC), National Commercial Bank 
Limited (NCCBL), Mercantile Bank Limited, Prime Bank Limited, Dutch Bangla Bank Limited, ICB Islami Bank Limited and Janata Bank (Table 4).

Table 4. Distribution of the Sample Respondents by Banks

\begin{tabular}{|c|c|c|c|c|}
\hline \multicolumn{2}{|c|}{ Banks Under Study } & \multirow{2}{*}{$\begin{array}{l}\text { Number of Respondents } \\
57\end{array}$} & \multirow{2}{*}{$\begin{array}{l}\text { Valid Percent } \\
19.0\end{array}$} & \multirow{2}{*}{$\begin{array}{l}\text { Cumulative Percent } \\
19.0\end{array}$} \\
\hline 1. & Dhaka Bank Ltd. & & & \\
\hline 2. & SBAC Bank & 21 & 7.0 & 26.0 \\
\hline 3. & NCC Bank Ltd & 36 & 12.0 & 38.0 \\
\hline 4. & Janata Bank & 49 & 16.3 & 54.3 \\
\hline 5. & Mercantile Bank Ltd & 50 & 16.7 & 71.0 \\
\hline 6. & Prime Bank Ltd & 25 & 8.3 & 79.3 \\
\hline 7. & Dutch Bangla Bank Ltd & 32 & 10.7 & 90.0 \\
\hline & ICB Islamic Bank & 30 & 10.0 & 100.0 \\
\hline Tot & & 300 & 100.0 & \\
\hline
\end{tabular}

Source: Survey Data, 2019.

\subsection{Sample Design and Determination of Sample Size}

At the end of June 2016, the total numbers of bank branches in Bangladesh are 9453 (Note 2). There are more than 100,000 employees in banking industry of Bangladesh in 58 banks of the country. Hence, the sample size of this study was determined by using the following formula suggested by Yamane (1967).

$$
n=\frac{N}{1+N(e)^{2}}
$$

Where, $n$ is the sample size, $N$ is the population size, and $e$ is the level of precision. For this study, level of precision is presumed as 0.07 and the population size is $1,00,000$. Putting these values in the above equation, the required number of sample size becomes approximately 204. This study interviewed 300 bank employees from 8 banks under study. This figure is well above the critical sample size of 204 for using multivariate analysis (Hair et al., 1998).

\subsection{Questionnaire Design}

The general objective of this study is to identify the factors of Off-The-Job Training effectiveness in commercial banks of Bangladesh. Accordingly, major variables for Off-The-Job training effectiveness were taken into account to develop the questionnaire. Hence, a five point Likert scale questionnaire was designed for the survey. The key variables or factors of Off-the-Job training effectiveness are: development of KSA (Knowledge, Skill and Ability), manager's cooperation, scope for self-assessment regarding training needs, training quality, TNA, training methods, training evaluation, job performance and confidence level of employees, and logistic support for training, etc.

\subsection{Data Collection and Data Analysis}

The primary source employed with the use of both qualitative and quantitative methods through the administration of questionnaires and interview of senior managers, head of branches and conducted survey to entry level to mid level employees. The data on quantitative and qualitative were analyzed through the use of SPSS and content analysis respectively.

\section{Results and Discussions}

The section discusses training importance to the trainees, the training policies of the commercial banks, and the results of factor analysis and multiple regression analysis.

\subsection{Training Importance, Training Policy and Trainers Performance}

Respondents were inquired whether academic knowledge and degrees are adequate to do banking jobs in commercial banks in Bangladesh or not. In response, $97.3 \%$ of the respondents expressed in favor of training apart from academic degree. They strongly believe that academic knowledge is not sufficient for banking job rather training enhances employees' operational abilities to perform financial activities and other specialized jobs of the banks (Table 5). 
Table 5. Response on academic knowledge is sufficient to perform banking activities

\begin{tabular}{|c|c|c|c|c|}
\hline $\begin{array}{l}\text { Response } \\
\text { Respondents }\end{array}$ & $\begin{array}{l}\text { of } \\
\text { Frequency }\end{array}$ & Percent & Valid Percent & Cumulative Percent \\
\hline Yes & 8 & 2.7 & 2.7 & 2.7 \\
\hline No & 292 & 97.3 & 97.3 & 100.0 \\
\hline Total & 300 & 100.0 & 100.0 & \\
\hline
\end{tabular}

Respondents were also asked about the HR training policy of the Banks. Majority (56.3\%) of the respondents opined that their banks do not have structured HR Training Policy. While, $43.7 \%$ answered that they have training policy in their banks (Table 6). Hence, it clear that the banks should have adequate training policy and budget for it.

Table 6. Response on HR Training Policy/Guidelines

\begin{tabular}{|c|c|c|c|c|}
\hline \multicolumn{5}{|c|}{ Response of } \\
\hline Respondents & Frequency & Percent & Valid Percent & Cumulative Percent \\
\hline Yes & 131 & 43.7 & 43.7 & 43.7 \\
\hline No & 169 & 56.3 & 56.3 & 100.0 \\
\hline Total & 300 & 100.0 & 100.0 & \\
\hline
\end{tabular}

Commercial banks in Bangladesh mostly depend on experienced bankers, in house faculty or skilled employees, to provide adequate training. Sometimes, banks outsource trainers from other banks, training academies, and organizations as per the requirements to conduct the training sessions through sharing their knowledge to ensure quality training at the banks. In this connection, $79 \%$ respondents are opined as positive and satisfied about the in house and outsource trainers providing quality training. However, $21 \%$ of the respondents did not agree about the training conducted by the present trainers. This percentage is quite significant because they believe trainers are not adequate and well equipped for providing quality training at their banks (Table 7).

Table 7. Trainers for Quality Training in Banks

\begin{tabular}{llllll}
\hline & & Frequency & Percent & Valid Percent & Cumulative Percent \\
\hline \multirow{3}{*}{ Valid } & Yes & 237 & 79.0 & 79.0 & 79.0 \\
& No & 63 & 21.0 & 21.0 & 100.0 \\
& Total & 300 & 100.0 & 100.0 & \\
\hline
\end{tabular}

Source: Survey Data, 2019.

\subsection{Results of Factor Analysis}

The study was conducted to identify the effectiveness factors of off-the-job training methods in commercial banks of Bangladesh. Factor analysis results show that the commonalities of the variables concerning workers' engagement are very high indicating that the data set has higher level of relationships among them (Table 8). 
Table 8. Commonalities of the effectiveness variables

\begin{tabular}{|c|c|c|}
\hline \multicolumn{2}{|c|}{ Variables } & \multirow{2}{*}{$\begin{array}{l}\text { Extraction } \\
.571\end{array}$} \\
\hline 1. & Off-the-job training helped me to acquire knowledge and skill on my job & \\
\hline 2. & Adequate importance is given by my department and organization on off-the-job training & .550 \\
\hline 3. & I could raise my voice regarding my skills and abilities in this training & .526 \\
\hline 4. & Training gave adequate importance to develop my skills and competence & .644 \\
\hline 5. & There was adequate emphasis on developing managerial capabilities & .447 \\
\hline 6. & Training was well planned & .543 \\
\hline 7. & Bank can be benefited from this training programs & .603 \\
\hline 8. & Employees are selected for this training programs on the basis of stated criteria & .410 \\
\hline 9. & Employees participated in determining the kind of training methods they need & .523 \\
\hline 10. & Training was transparent to me & .541 \\
\hline 11. & Adequate funds are allocated for the implementation of the training & .575 \\
\hline 12. & Feedback was given concerning training contributions to the organizational objectives & .543 \\
\hline 13. & Training was frequently evaluated and lastly improved my performance & .509 \\
\hline 14. & Training provided opportunity for newcomers to learn about the bank & .509 \\
\hline 15. & The course content of the training program was relevant and easy to follow & .529 \\
\hline 16. & The training was given in a pace which was understandable to me & .562 \\
\hline 17. & Training improved my performance at work & .691 \\
\hline 18. & My confidence at work was improved after the training & .717 \\
\hline 19. & Instructor was knowledgeable and experienced for this training & .587 \\
\hline 20. & Instructor invited comments and participation of the trainees & .513 \\
\hline 21. & Training location was excellent and attractive to me & .619 \\
\hline 22. & All the logistic supports were available during the training & .702 \\
\hline 23. & Foods and snacks were enjoyable for me & .565 \\
\hline 24. & There was no disturb at the time of training & .523 \\
\hline 25. & I am satisfied with this training given by my bank & .569 \\
\hline
\end{tabular}

Extraction Method: Principal Component Analysis.

Factors analysis results also show that there are four factors related to the effectiveness of the off-the-job training methods in commercial banks of Bangladesh. The factors are: (i) acquiring of knowledge and skills, (ii) logistics support, (iii) invitation of comments and participation of the trainees, (iv) trainees participation in training needs assessment (Table 9). The most important factor is acquiring of knowledge and skills (42.74\%) followed by logistics support $(8.36 \%)$, invitation of comments and participation of the trainees $(5.17 \%)$, and trainees' participation in training needs assessment (3.82).

Table 9. Total Variance Explained by the Effectiveness Factors

\begin{tabular}{llll}
\hline & \multicolumn{2}{l}{ Initial Eigenvalues } \\
\cline { 2 - 4 } Factors & Total & \% of Variance & Cumulative \% \\
\hline 1. Acquiring of Knowledge and Skills & 10.686 & 42.743 & 42.743 \\
2. Logistics Support & 2.090 & 8.360 & 51.103 \\
3. Invitation of Comments and Participation of the Trainees & 1.293 & 5.173 & 56.276 \\
4. Trainees Participation in Training Needs Assessment & .954 & 3.816 & 60.092 \\
\hline
\end{tabular}

Extraction Method: Principal Component Analysis. 
Table 10 shows the rotated component matrix of the effectiveness of off-the-job training methods in commercial banks of Bangladesh. It shows that all the factors constituted by the variables have higher level of factor loading indicating that the variables have higher level relationships with the effectiveness factors.

\section{Acquiring Knowledge and Skills}

This study found that the employees see off-the-job training as important method for acquiring more knowledge and managerial capabilities. It improves employee skills and work performance.

\section{Logistic Support}

In banks, logistic support related to training referred as foods and snacks provided during training, location, seating arrangement, venue environment, training quality, absence of distraction in class, eequipment (sound system, High Quality board etc), facilities (accommodation for longer training), technical information (content, e-reading material, etc). Through the logistic support, trainer and trainee relationship becomes more interactive and reciprocal.

\section{Scope of Participants' Class Engagement}

Allowing trainees to speak and share their opinions and comments enable trainer to deliver effective lecture. Both way response improves class participation and thus enhance more understanding of participant regarding the content of the training.

\section{Trainees Participation in Training Need Assessment (TNA)}

Training Need Assessment (TNA) is to be conducted before planning the training. In this accord, training evaluation will be easier and revised plan might be formulated for further improvement.

Table 10. Rotated component matrix ${ }^{\mathrm{a}}$

\begin{tabular}{llcc}
\hline Variables & Factors & \\
& & \\
& 1 & 2 & 3 \\
\hline
\end{tabular}

Factor 1 Acquiring of Knowledge and Skills

Off-the-job training helped me to acquire knowledge and skill on my job $\quad .704$

Adequate importance is given by my department and organization on off-the-job training $\quad 689$

I could raise my voice regarding my skills and abilities in this training .688

Training gave adequate importance to develop my skills and competence $\quad .676$

$\begin{array}{ll}\text { Training improved my performance at work } & .641\end{array}$

Bank can be benefited from this training programs $\quad .641$

There was adequate emphasis on developing managerial capabilities $\quad .471$

Factor 2 Logistics Support

All the logistic supports were available during the training .811

Foods and snacks were enjoyable for me .760

Training location was excellent and attractive to me $\quad .725$

I am satisfied with this training given by my bank .679

There was no disturb at the time of training .624

It was well planned $\quad .472$

Training was transparent to me $\quad .426$

Factor 3 Invitation of Comments and Participation of the Trainees

Instructor invited comments and participation of the trainees .704

Instructor was knowledgeable and experienced for this training .694

My confidence at work was improved after the training .647

Training provided opportunity for newcomers to learn about the bank .637

The course content of the training program was relevant to follow .605

The training was given in a pace which was understandable to me .533 


\section{Factor 4 Trainees Participation in Training Needs Assessment}

Employees participated in determining required training methods .726

Feedback was given concerning training contributions to the organizational objectives .589

Adequate funds are allocated for the implementation of the training $\quad .570$

Employees selection for the training programs on basis of stated criteria $\quad .509$

Training was frequently evaluated and lastly improved my performance $\quad .438$

Extraction Method: Principal Component Analysis.

Rotation Method: Varimax with Kaiser Normalization.

a. Rotation converged in 9 iterations.

a. Predictors: (Constant), REGR factor score 4 for analysis 3, REGR factor score 3 for analysis 3, REGR factor score 2 for analysis 3, REGR factor score 1 for analysis 3.

\subsection{Results of Regression Analysis}

The results of regression analysis show that all the four effectiveness factors of the off-the-job training methods in commercial banks of Bangladesh can explain the dependent variable by $55 \%$ ( $\mathrm{R}$ Square) indicating that the model is important (Table 11). This study covered 55\% of the factors that have connection with the effectiveness of the off-the-job training methods in commercial banks of Bangladesh. The other factors, which were not covered in this study, might be concerned with the external factors which are beyond the control of the trainees.

Table 11. Model Summary ${ }^{\mathrm{a}}$

\begin{tabular}{lllll}
\hline Model & R & R Square & Adjusted R Square & Std. Error of the Estimate \\
\hline 1 & $.742^{\mathrm{a}}$ & .550 & .544 & .465
\end{tabular}

a. Predictors: (Constant), REGR factor score 4 for analysis 3, REGR factor score 3 for analysis 3, REGR factor score 2 for analysis 3 , REGR factor score 1 for analysis 3

Analysis of variance (ANOVA) shows that four factors are significantly related to the overall effectiveness of the off-the-job training methods in commercial banks of Bangladesh (Table 12).

Table 12. ANOVA $^{\mathrm{b}}$

\begin{tabular}{lllll}
\hline Model & Sum of Squares & df & Mean Square & F \\
\hline Regression & 77.882 & 4 & 19.470 & 90.091 \\
Residual & 63.755 & 295 & .216 & $.000^{\mathrm{a}}$ \\
Total & 141.637 & 299 & & \\
\hline
\end{tabular}

a. Predictors: (Constant), REGR factor score 4 for analysis 3, REGR factor score 3 for analysis 3, REGR factor score 2 for analysis 3, REGR factor score 1 for analysis 3 .

b. Dependent Variable: Considering all the factors mentioned above I think the off-the-job training given to me was effective.

The individual factor relationships with the overall effectiveness of the off-the-job training methods in commercial banks of Bangladesh show that all four factors such as, acquiring of knowledge and skills, (ii) logistics support, (iii) invitation of comments and participation of the trainees, (iv) trainees participation in training needs assessment are significantly related to the overall effectiveness of the off-the-job training methods in commercial banks of Bangladesh (Table 13). This means, if there is a change of each of these factors there will be a significant change in the overall effectiveness of the off-the-job training methods in the banks. 
Table 13. Coefficients ${ }^{\mathrm{a}}$

\begin{tabular}{|c|c|c|c|c|c|}
\hline \multirow[b]{2}{*}{ Model } & \multicolumn{2}{|c|}{ Unstandardized Coefficients } & $\begin{array}{l}\text { Standardized } \\
\text { Coefficients }\end{array}$ & \multirow[b]{2}{*}{$\mathrm{t}$} & \multirow[b]{2}{*}{ Sig. } \\
\hline & $\mathrm{B}$ & Std. Error & Beta & & \\
\hline (Constant) & 4.177 & .027 & & 155.612 & .000 \\
\hline Acquiring of Knowledge and Skills & .314 & .027 & .457 & 11.695 & .000 \\
\hline Logistics Support & .290 & .027 & .422 & 10.796 & .000 \\
\hline $\begin{array}{l}\text { Invitation of Comments and Participation of } \\
\text { the Trainees }\end{array}$ & .242 & .027 & .352 & 9.006 & .000 \\
\hline $\begin{array}{l}\text { Trainees Participation in Training Needs } \\
\text { Assessment }\end{array}$ & .137 & .027 & .199 & 5.093 & .000 \\
\hline
\end{tabular}

a. Dependent Variable: Considering all the factors mentioned above I think the off-the-job training given to me was effective.

Source: SPSS Data Analysis.

\section{Conclusions and Recommendations}

This study aims for the identification of the factors concerning the effectiveness of off-the-job training methods in commercial banks of Bangladesh. Majority of the trainees think that training is important for enhancing their skills and banking knowledge to perform error-free transactions and others operational and technical jobs in banks. They agreed on degree is not enough in this regards. However, majority banks do not have training policy that can ensure effectiveness of the off-the-job training of their employees. In-house trainers and outsourced expert trainers are more effective for effective off-the-job training in the banks.

This study identified that there are four factors related to the effectiveness of the off-the-job training methods in commercial banks of Bangladesh such as, acquiring knowledge and skills, logistics support, inviting comments and participation of the trainees, trainees' participation in training needs assessment process. The most important factor is acquiring of knowledge and skills through training. The analysis also shows that all the effectiveness factors of the off-the-job training methods in commercial banks of Bangladesh are significantly related to the overall effectiveness of the off-the-job training methods. This means, if there is a change of each of these factors there will be a significant change in the overall effectiveness of the off-the-job training methods in the banks. This study recommends that the off-the-job training methods can be made effective by ensuring delivery of knowledge and skills, confirming logistics support, engaging the trainees in the training session and making sure that the trainees are participating in training needs assessment process. This study only identified the factors related to the effectiveness of the off-the-job training methods in commercial banks of Bangladesh. However, there is an ample scope to conduct further study to identify the effectiveness factors of on-the-job training methods in commercial banks of Bangladesh.

\section{References}

Aguinis, H., \& Kraiger, K. (2009). Benefits of training and development for individuals and teams, organizations, and society. Annual Review of Psychology, 60, 451-474. https://doi.org/10.1146/annurev.psych.60.110707.163505

Alipour, M., Salehi, M., \& Shahnavaz, A. (2009). A study of on the job training effectiveness: Empirical evidence of Iran. International Journal of Business and Management, 4(11), 63-68. https://doi.org/10.5539/ijbm.v4n11p63

Altarawneh, I. (2009). Training and Development Evaluation in Jordanian Banking Organisations. Research \& Practice in Human Resource Management, 17(1).

Amin, A., Saeed, R., Lodhi, R. N., Mizna, S., Iqbal, A., \& Tehreem, R. (2013). The impact of employees training on the job performance in education sector of Pakistan. Middle-East Journal of Scientific Research, 17(9), 1273-1278.

Ardichvili, A., \& Gasparishvili, A. (2001). Human resource development in an industry in transition: the case of the Russian banking sector. Human Resource Development International, 4(1), 47-63. https://doi.org/10.1080/13678860122157

Atiyyah, H. (1993). Management development in Arab countries: The challenges of the 1990s. Journal 
ofManagement Development, 12(1), 3-12. https://doi.org/10.1108/02621719310024336

Bandura, A., \& Walters, R. H. (1977). Social learning theory (Vol. 1). Englewood Cliffs, NJ: Prentice-hall.

Banna, B. (1995). Human Resource in Tanzania Local Government Institutions. The Case of Dar es Salaam City Council. Unpublished Material, M. A Dissertation, University Of Dar es salaam.

Brown, C. V., \& Bostrom, R. P. (1994). Organization designs for the management of end-user computing: Reexamining the contingencies. Journal of Management Information Systems, 10(4), 183-211. https://doi.org/10.1080/07421222.1994.11518025

Ewain, S. A. (2005). State-of-The-Art Technologies Used in Training Delivery and Administration at the Institute of Public Administration: Case Study. Online Submission, 2(11), 36-40.

Falola, H. O., Osibanjo, A. O., \& Ojo, I. S. (2014). Effectiveness of training and development on employees' performance and organization competitiveness in the Nigerian banking industry. Bulletin of the Transylvania University of Brasov, 7(1), 161.

Hameed, D. S. S., Rajinikanth, J., \& Mohanraj, P. (2014). A Conceptual Study on Training and Development Programs of Bank Employees. International Journal of Advance Research in Computer Science and Management Studies, 2(5).

Holland, J. (2010). Banks, knowledge and crisis: a case of knowledge and learning failure. Journal of Financial Regulation and Compliance, 18(2), 87-105. https://doi.org/10.1108/13581981011033961

Jantan, M. A., \& Honeycutt Jr, E. D. (2013). Current sales training practices in the commercial retail banking industry in Malaysia. Services Marketing Quarterly, 34(1), 1-17. https://doi.org/10.1080/15332969.2013.739876

Karadimas, N. V., \& Rigopoulos, G. (2006). Enhancing IT skills of banking employees through elearning technology. WSEAS Transactions on Computers, 5(12), 3165-3168.

Khanna, A., \& Arora, B. (2009). A study to investigate the reasons for bank frauds and the implementation of preventive security controls in Indian banking industry. International Journal of Business Science \& Applied Management (IJBSAM), 4(3), 1-21.

Mohamad, A. A., Lo, M. C., \& La, M. K. (2009). Human Resource Practices And Organizational Performance. Incentives As Moderator. Journal of Academic Research in Economics, 1(2).

Morgan, R. B., \& Casper, W. J. (2000). Examining the factor structure of participant reactions to training: A multidimensional approach. Human resource Development Quarterly, 11(3), 301-317. https://doi.org/10.1002/1532-1096(200023)11:3<301::AID-HRDQ7>3.0.CO;2-P

Ostrowski Martin, B., \& Kolomitro, K., \& Lam, T. (2013). Training Methods: A Review and Analysis. Human Resource Development Review, 13, 11-35. https://doi.org/10.1177/1534484313497947

Raja, A. G. K., Furqan, A. K., \& Muhammad, A. K. (2011). Impact of Training and Development on Organizational Performance. Global Journal of Management and Business Research, 11(7).

Smith, E. (2002). Theory and practice: The contribution of off-the-job training to the development of apprentices and trainees. Journal of vocational education and training, 54(3), 431-456. https://doi.org/10.1080/13636820200200208

Van Den Besselaar, P., \& Sandström, U. (2016). Gender differences in research performance and its impact on careers: a longitudinal case study. Scientometrics, 106(1), 143-162. https://doi.org/10.1007/s11192-015-1775-3

Yamane, T. (1967). Determining sample size for research activities. J. Educ. Psychol. Meas.

\section{Notes}

Note

https://www.dhakatribune.com/business/2018/11/18/over-3-000-bank-branches-established-in-the-last-10-years

Note 2. https://www.academia.edu/34969653/Banking_Sector_of_Bangladesh_-_An_Overview.docx 


\section{Copyrights}

Copyright for this article is retained by the author(s), with first publication rights granted to the journal.

This is an open-access article distributed under the terms and conditions of the Creative Commons Attribution license (http://creativecommons.org/licenses/by/4.0/). 